\title{
Comparison of Preanalytical Sample Stability between Serum and Ethylenediaminetetraacetic Acid Plasma for the Measurement of Biological Analytes
}

\author{
Jiwon Lee, Kibeom Jeon, Taekha Lee, Jisoo Lee, Miyoung Kim, Han-Sung Kim, Young Kyung Lee, and \\ Hee Jung Kang \\ Department of Laboratory Medicine, Hallym University Sacred Heart Hospital, Anyang, Korea
}

\section{Corresponding author:}

Hee Jung Kang

Department of Laboratory Medicine, Hallym University Sacred Heart Hospital, 22 Gwanpyeong-ro 170beongil, Dongan-gu, Anyang 14068, Korea Tel +82-31-380-3929

Fax +82-31-380-1798

E-mail kangheejung@hallym.or.kr

Received: December 18, 2019

Revised: February 19, 2020

Accepted: February 21, 2020
This is an Open Access article distributed under the terms of the Creative Commons Attribution Non-Commercial License (http://creativecommons.org/licenses/ by-nc/4.0) which permits unrestricted non-commercial use, distribution, and reproduction in any medium, provided the original work is properly cited.
Background: In this study, we aim to examine the effects of pre-analytical factors such as specimen type (serum or plasma), collection and storage conditions, and time, on the results of chemiluminescence immunoassay.

Methods: Blood samples were collected from 10 individuals and aliquoted into two sets of K3-ethylenediaminetetraacetic acid (EDTA) and serumseparating tubes (SST) each, for plasma and serum collection, respectively. For all the samples, one set of tubes was centrifuged within 1 hour and other set was centrifuged after 4 hours, followed by cell separation. Chemiluminescence assay was performed for adrenocorticotropic hormone (ACTH), parathyroid hormone (PTH), osteocalcin, C-telopeptide, and insulin at $0,6,24$, and 48 hours after centrifugation; all the samples were assayed in duplicate. The samples were stored at $4^{\circ} \mathrm{C}$ before the assay.

Results: The results obtained showed that the levels detected in plasmas were more consistent and stable as compared to serum. After a 6-hour storage at $4^{\circ} \mathrm{C}$, a significant decrease was observed in the levels of ACTH and osteocalcin in plasma and serum; whereas, PTH and C-telopeptide levels were stable in plasma but decreased significantly in serum. Insulin levels in serum showed a decrease after a 6-hour storage while the levels in plasma were found to be stable until 24-hour storage. Serum samples separated after 4 hours showed a significant decrease in all hormone levels, while $\mathrm{C}$-telopeptide and insulin levels were stable in plasma samples separated after 4 hours.

Conclusions: The results were found to be more stable in plasma samples from K3-EDTA tubes as compared to serum samples from SST in the measurement of unstable biological analytes. These results suggest that K3EDTA tubes are preferable in the specimen collection for assaying biological analytes.

(Lab Med Qual Assur 2020;42:140-149)

Key Words Plasma, Serum, Delayed centrifugation, Stability of analytes 
서론

임상검사실에서 생물학적 분석물질의 측정 시 검체 내에서의 시간에 따라 자연적으로 발생하는 단백 분해가 검사결과에 영향을 미칠 수 있다. 검체 채취 튜브의 종류, 검체 채취 후 혈청(혹은 혈 장) 분리까지의 시간, 검체 보관온도 및 보관시간 등 여러 요인들 이 분석 전 오차의 원인이 될 수 있다[1,2]. 따라서 World Health Organization 권고안[3], Clinical and Laboratory Standards Institute 지침[4] 등이 분석물질의 안정성이 담보되는 검체 채취 후 분석까지 과정의 표준화와 관리방법을 제시하고 있다. 하지만 실제 현장에서 모든 검사의 검체 처리와 운송이 문헌에 제시된 분 석물질 안정시간 내에 이루어지기 어려운 경우가 많다[5]. 예를 들 면 전혈 내에서 potassium과 phosphate 안정시간이 1 시간 이 내이니 모든 혈액 검체는 1 시간 이내에 적어도 혈청(혈장) 분리가 이루어져야 하는데, 검체를 채취하는 주체가 이러한 분석 전 오차 의 가능성을 숙지하지 못한 경우 검체 처리과정의 주의가 간과될 수 있다[3]. 일선 병원에서는 체외진단검사의 이용에 있어 비용 대 비 효율성의 제고를 위하여 검사실의 상황이나 담당 전문의의 판 단에 의해 일부 검사를 상시 검사 대신 특정 요일에 검체를 모아서 검사하거나 자체 검사실이 있어도 외부기관으로 위탁하여 수행하 는 경우도 있다. 이러한 경우 장기간 검체 보관에 따른 유의한 분 석 전 오차가 발생할 가능성이 존재한다.

미량의 호르몬이나 골 표지자들은 과거 방사성동위원소를 이용 한 면역검사로 측정하였으나 최근 화학발광면역측정기로 측정이 가능하여 그 활용이 확대되고 있다. 화학발광면역측정기는 다종의 검사물질을 한 장비에서 함께 측정하므로 임상검사실에서는 쉽게 검사항목을 추가할 수 있고, 한 번의 채혈로 여러 검사결과를 한꺼 번에 알 수 있어 환자의 편익면에서도 유용하다. 하지만 이런 편이 성으로 인하여 개개 검사 특성에 대한 고려 없이 검사종목을 확대 하고 일률적으로 검체 채취하고 처리한 경우 검사종목에 따라 분 석 전 오차가 발생할 수 있다. 이러한 분석 전 오차는 검사실의 내 부정도관리나 외부정도관리 활동으로 오류를 검출할 수 없기 때 문에, 검사실이 이를 인지하지 못하고 검사를 수행하게 된다. 특히 일부 검사물질들은 통상적으로 사용하는 검체 종류인 혈청에서 쉽 게 파괴되어 검사결과에 오류를 초래할 수 있는 것으로 알려져 있 고[5], 제조사 시약설명서에 명기되어 있음에도 불구하고 국내 임 상검사실이나 검사 수탁기관에서는 통상적인 수준에서 검체 처리 를 관리하고 있다.

본 연구는 화학발광면역측정법 검사 중 분석물질이 불안정한 검사항목을 중심으로 검체 종류 및 보관조건에 따른 검사결과의 변화를 확인하여 보다 안정적인 검체 처리과정을 도출하고자 하였 다.

\section{재료 및 방법}

\section{1. 대상 항목 선정}

국내에서 한국로슈사와 한국에보트사의 화학발광면역측정기 에서 측정이 가능한 검사 시약설명서를 검토하여 호르몬, 골대사 표지자 중 검체 내 분석물질의 안정성 유지에 주의를 요하도록 명 기된 항목을 조사하여 adrenocorticotropic hormone (ACTH), parathyroid hormone (PTH), osteocalcin, C-telopeptide, insulin 검사를 연구대상 항목으로 선정하였다[6-10] (Table 1).

\section{2. 대상 검체}

대상 검체는 건강검진자의 검체를 이용하였으며 대상자 동의 는 면제되었고 기관윤리위원회의 연구승인을 득하였다(HALLYM NON2019-001). 혈청과 혈장의 분리시간과 보관조건이 검사 결과에 미치는 영향을 평가하기 위해 K3-ethylenediaminetetraacetic acid (EDTA) 튜브와 혈청분리 튜브(serumseparating tube, SST)에 채취한 총 10 인의 전혈을 이용하였다.

\section{3. 연구방법}

K3-EDTA 튜브와 SST에 채취한 각 두 개의 검체에서 한 튜브 는 검체 채취 후 1 시간 내에(1시간 내 검체 분리), 나머지 한 튜브 는 4시간 실온에 두었다가 원침하여(4시간 지연 검체 분리) 혈청 혹은 혈장을 분리하였다. 각 검체별로 검체 분리 직후(0시간)와 냉장에서 6 시간(1시간 내 검체 분리 검체만), 24 시간, 그리고 48 시간 냉장 보관한 시점에 검사하였다. 각 검체들은 $\mathrm{ACTH}, \mathrm{PTH}$, osteocalcin, C-telopeptide는 Cobas e801 immunoassay analyzer (Roche Diagnostics Corp., Indianapolis, IN, USA) 로 insulin은 Architect i2000SR (Abbott Laboratories, Abbott Park, IL, USA) 화학발광면역측정기에서 각 전용 시약을 이용하 여 중복 측정하였다.

\section{4. 통계}

혈청(혈장) 검체 분리 직후(0시간)와 각 보관시간(6시간, 24 시 간, 48 시간)이 지난 검체 검사 결과값의 차이, 그리고 1 시간 내 분 리된 검체와 4 시간 지연 분리한 검체들의 결과값을 비교하는 데 에는 Wilcoxon signed-rank test를 이용하여 비교 분석하였다. 일정 시간 보관 후 K3-EDTA 튜브와 SST 검체의 검사 결과값 변 화 간의 차이를 비교할 때는 각 튜브의 1 시간 내 분리된 검체를 $100 \%$ 로 기준하여 상대적인 값으로 비교하였다. 통계분석은 IBM SPSS Statistics for Windows ver. 24.0 (IBM Corp., Armonk, $\mathrm{NY}, \mathrm{USA}$ )를 이용하였다. 유의수준은 $P<0.05$ 로 검정하였다. 


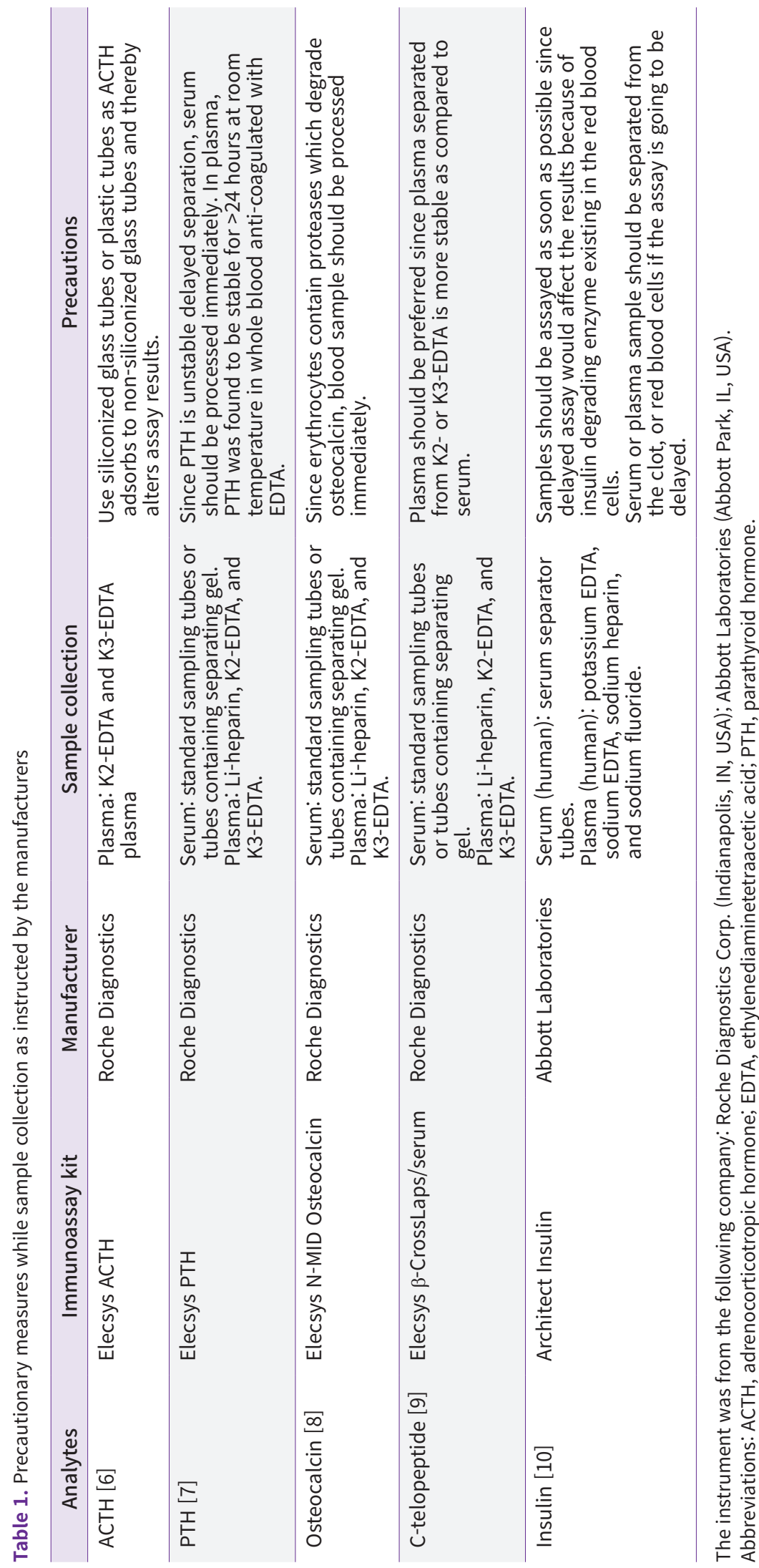




\section{결과}

\section{1시간 내 검체 분리 시 혈장과 혈청의 검사결과 비교}

K3-EDTA 튜브와 SST에서 채혈 1시간 이내에 원심분리하 여 얻은 혈장과 혈청에서의 검사결과를 비교하였다. 5종 검사 항목 중 $\mathrm{ACTH}$ 는 유의하게 혈장보다 혈청에서 수치가 높았으며 osteocalcin은 혈청에서 유의하게 낮은 결과를 보였으나 차이의
95\% 신뢰구간이 0을 포함하는 수준이었다(Table 2, Fig. 1). PTH 도 혈청에서 낮은 결과를 보이는 경향이었으나 $95 \%$ 신뢰구간이 0 을 포함하였고 경계수준의 $P$ 값을 보였다.

\section{4시간 지연 검체 분리의 검사결과에 미치는 영향}

K3-EDTA 혈장은 원심분리를 4 시간 지연하여 검체 분리하여 검 사하여도 1 시간 내 검체 분리 후 바로 검사를 시행한 경우와 비교

Table 2. Difference in the levels if biological analyte measured in plasma and serum separated within 1 hour after blood collection

\begin{tabular}{lccccc}
\hline \multirow{2}{*}{ Analytes } & \multicolumn{2}{c}{ Range } & & $\begin{array}{c}\text { Median difference } \\
\text { (95\% confidence interval) }\end{array}$ & $P$-value \\
\cline { 2 - 3 } & K3-EDTA plasma & SST serum & & $-4.3(-6.25$ to -1.15$)$ & 0.020 \\
\hline ACTH $(\mathrm{pg} / \mathrm{mL})$ & 6.8 to 46.9 & 12.6 to 55.0 & & 2.6 (-0.75 to 4.0$)$ & 0.065 \\
\hline PTH $(\mathrm{pg} / \mathrm{mL})$ & 35 to 63 & 30.4 to 59.2 & & $0.8(-0.35$ to 1.2$)$ & 0.004 \\
\hline Osteocalcin $(\mathrm{ng} / \mathrm{mL})$ & 13.5 to 40.1 & 13.6 to 39.7 & & $-0.004(-0.018$ to 0.0065$)$ & 0.426 \\
\hline C-telopeptide $(\mathrm{ng} / \mathrm{mL})$ & 0.128 to 0.269 & 0.132 to 0.265 & & $-0.05(-0.25$ to 0.3$)$ & 0.770 \\
\hline Insulin $(\mu \mathrm{U} / \mathrm{mL})$ & 3.3 to 12.4 & 3.6 to 11.5 & & \\
\hline
\end{tabular}

Bold type is considered statistically significant.

Abbreviations: EDTA, ethylenediaminetetraacetic acid; SST, serum-separating tube; ACTH, adrenocorticotropic hormone; PTH, parathyroid hormone.
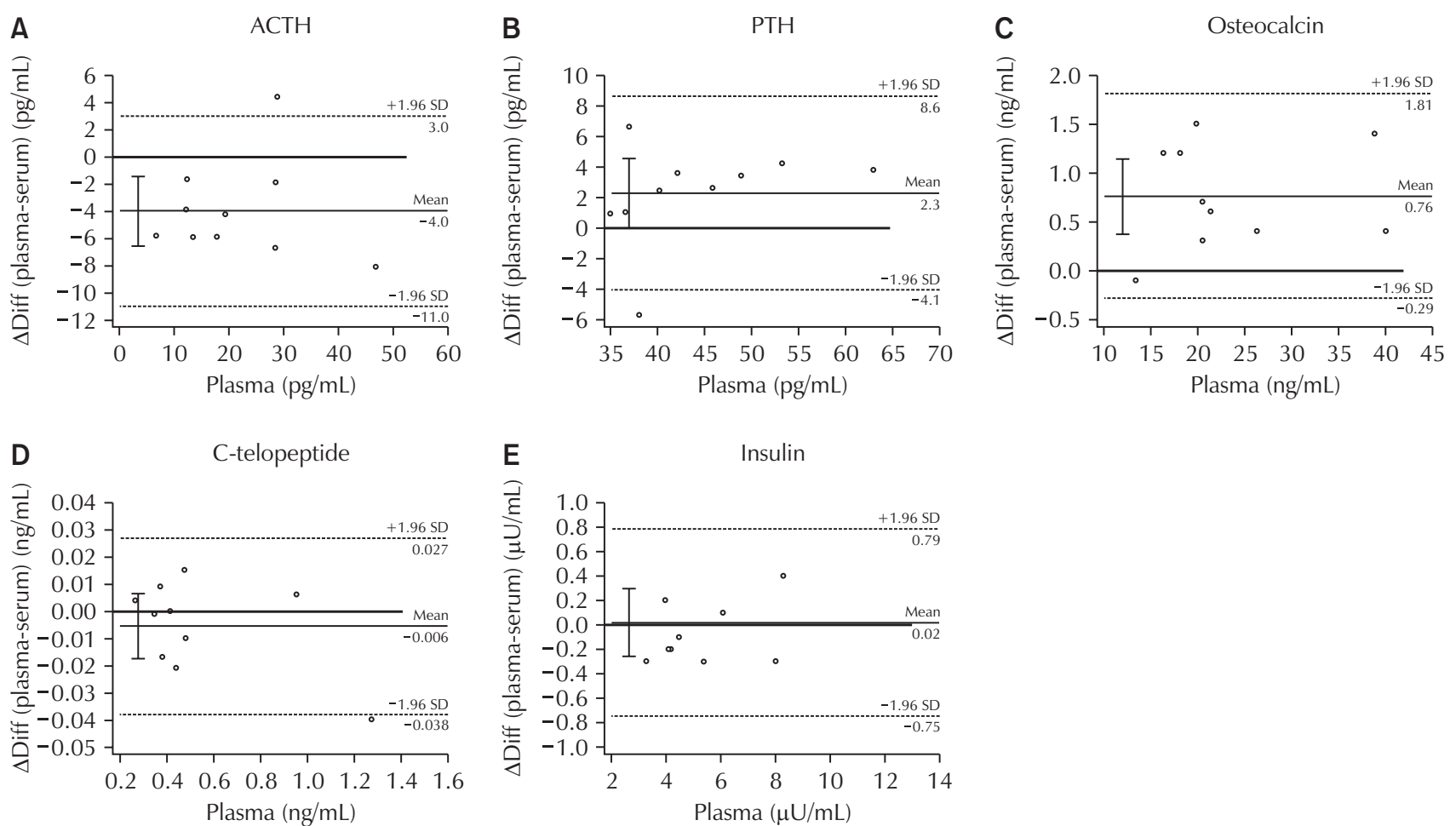

Fig. 1. (A-E) Difference plot illustrating the levels of biological analyte in plasma and serum samples separated within 1 hour after collection. Each group represents mean values obtained from 10 individuals $(\mathrm{N}=10)$. Solid lines and dotted lines represent mean difference and $95 \%$ confidence interval, respectively. $\triangle$ Diff represents difference in the analyte levels. Abbreviations: ACTH, adrenocorticotropic hormone; PTH, parathyroid hormone; SD, standard deviation. 
하여 ACTH, PTH, C-telopeptide, insulin에서 유의한 차이를 보 이지 않았고 osteocalcin만 유의한 감소를 보였다(Table 3, Fig. 2). 이에 비하여 SST에서 얻은 혈청은 insulin을 제외하고 나머지 4종목에서 모두 유의한 감소를 보였다. 혈청에서는 4 시간 검체 분 리 지연 시 ACTH 값의 현격한 저하가 관찰되었다.

\section{3. 각 보관시간에서의 검사결과 비교}

K3-EDTA 혈장이나 SST 혈청 대다수에서 1 시간 내 검체 분리하 여 냉장보관하여도 즉시 검사(0시간)한 결과값에 비하여 보관하였 다. 검사한 경우 검사 값이 감소하는 경향을 보였다(Fig. 3). ACTH 와 osteocalcin은 혈장과 혈청 모두 냉장보관 6 시간 후에서도 유 의하게 감소하였다. 하지만 PTH와 C-telopeptide는 혈장에서는 냉장보관 6시간까지는 차이가 유의하지 않고 24시간, 48시간에서 유의한 감소를 보인 반면, 혈청은 냉장보관 6 시간 검체부터 유의 하게 감소하였다. Insulin도 혈장에서는 냉장보관 6시간, 24시간 까지 차이가 없었고 48시간 경과 후에 유의한 감소를 보였으나 혈 청에서는 냉장보관 6 시간 검체부터 유의한 감소가 관찰되었다.

검사 지연에 따른 결과의 상대적 변화를 혈장과 혈청 간 비교하 였을 때, C-telopeptide를 제외하고 나머지 4항목에서 혈장보다 혈청에서 감소폭이 컸는데, ACTH와 PTH는 냉장보관 6시간, 24 시간, 48시간 모두에서, osteocalcin은 냉장보관 6시간, 24시간 후 결과에서, insulin은 냉장보관 6시간 후 결과에서 통계적으로 유의한 차이를 보였다.

4시간 지연 검체 분리한 혈장과 혈청도 유사한 결과를 보였는 데, $\mathrm{ACTH}, \mathrm{PTH}$, osteocalcin, C-telopeptide에서 지연 검체 분 리 후 또 그 검체를 24시간 또는 48시간 냉장보관하였을 때 혈장 보다 혈청에서 감소 폭이 유의하게 컸다(Fig. 4). Insulin도 4시 간 지연 검체 분리 후 바로 검사하였을 때나 24시간 냉장보관하 였다가 검사하였을 때 혈청에서 유의하게 검사결과가 감소하였 고 혈장에서는 결과치 감소가 유의하지 않았다. 혈장은 48시간 냉
장보관한 시점에서 유의한 감소를 보였다. 하지만 혈장과 혈청 간 insulin 결과치 감소의 차이는 통계적으로 유의하지 않았다.

\section{고찰}

여러 분석 전 인자들이 검체의 안정성에 영향을 미치는 것으로 알려져 있고, 이 중 검사 전 소요시간과 검체 운반조건 등은 검사 결과에 유의한 영향을 미치는 것으로 알려져 있다[11]. 검사종목 마다 이러한 영향의 정도가 달라 일부 종목은 검사 지연시간 및 검체 조건에 대하여 통상적인 조건보다 엄격한 관리가 필요하다. 본 연구에서는 검사 시약설명서에 검체 조건에 대하여 보다 엄격 한 유의사항이 기술되어 있는 검사들을 조사하여 ACTH, PTH, osteocalcin, C-telopeptide, insulin 검사를 대상으로 선정하였 다[6-10]. 이들 검사를 대상으로 검체 채취 튜브의 종류, 원심분리 의 지연, 검사의 지연의 영향을 확인한 바, 이러한 분석 전 인자들 이 이들 항목의 검사결과에 영향을 미치며 혈청보다 K3-EDTA 혈 장에서 검사결과가 상대적으로 안정한 것을 알 수 있었다. 이러한 연구결과는 검체 이송 등으로 불가피하게 검사가 지연될 수밖에 없는 현실에서 이들 검사를 시행할 때는 혈액 채취 시 SST보다는 K3-EDTA 튜브를 이용한 혈장으로 검사하는 것이 적합하다는 근 거를 제시한다.

한 검사실에서 모든 검사항목을 다 시행하는 것은 불가능하며 일부 검사들을 위탁하는 것은 피할 수 없는 일이다. 하지만 이러한 검사의 위탁과정에 따른 여러 요인으로 분석 전 오차가 더 커질 수 밖에 없다. 일부 연구에서는 모든 검체 운송 소요시간에 따른 분 석 전 영향을 최소화하기 위한 방안으로 검체 보관 및 운반온도는 $20^{\circ} \mathrm{C}-25^{\circ} \mathrm{C}$ 를 유지하며, 채혈현장에서의 원심분리 필요성을 없애 기 위하여 하루 2차례 검체를 수거하며, 원심분리 전 검체 보관시 간은 6시간을 제한하는 방안이 제시되기도 하였다[12]. 국내 수탁 검사실에서는 검체의 우송 전 혈청분리, 우송 중 검체의 냉장보관

Table 3. Effects on the levels of biological analyte measured in plasma and serum separated 4 hours after blood collection

\begin{tabular}{lcccccc}
\hline \multirow{2}{*}{ Analytes } & \multicolumn{2}{c}{ Plasma: relative value $(\%)^{*}$} & & \multicolumn{2}{c}{ Serum: relative value $(\%)^{*}$} \\
\cline { 2 - 3 } \cline { 5 - 7 } & Median (IQR) & $P$-value & & Median (IQR) & $P$-value \\
\hline ACTH $(\mathrm{pg} / \mathrm{mL})$ & $101.9(98.2-115.2)$ & 0.208 & & $68.9(66.6-73.4)$ & $\mathbf{0 . 0 0 5}$ \\
\hline PTH $(\mathrm{pg} / \mathrm{mL})$ & $98.7(97.1-104.2)$ & 0.878 & & $93.4(90.8-98.7)$ & $\mathbf{0 . 0 1 3}$ \\
\hline Osteocalcin $(\mathrm{ng} / \mathrm{mL})$ & $97.9(95.8-99.6)$ & $\mathbf{0 . 0 4 2}$ & & $96.0(93.7-97.9)$ & $\mathbf{0 . 0 0 8}$ \\
\hline C-telopeptide $(\mathrm{ng} / \mathrm{mL})$ & $99.6(97.9-101.9)$ & 0.646 & & $96.8(94.8-98.5)$ & $\mathbf{0 . 0 0 9}$ \\
\hline Insulin $(\mu \mathrm{U} / \mathrm{mL})$ & $101.4(97.4-106.4)$ & 0.230 & & $99.7(98.4-101.8)$ & 0.546 \\
\hline
\end{tabular}

Bold type is considered statistically significant.

Abbreviations: IQR, interquartile range; ACTH, adrenocorticotropic hormone; PTH, parathyroid hormone.

${ }^{\star}$ Compared to the values obtained from samples separated within 1 hour after collection. 


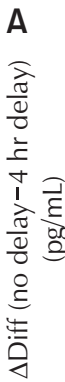

ACTH (plasma)

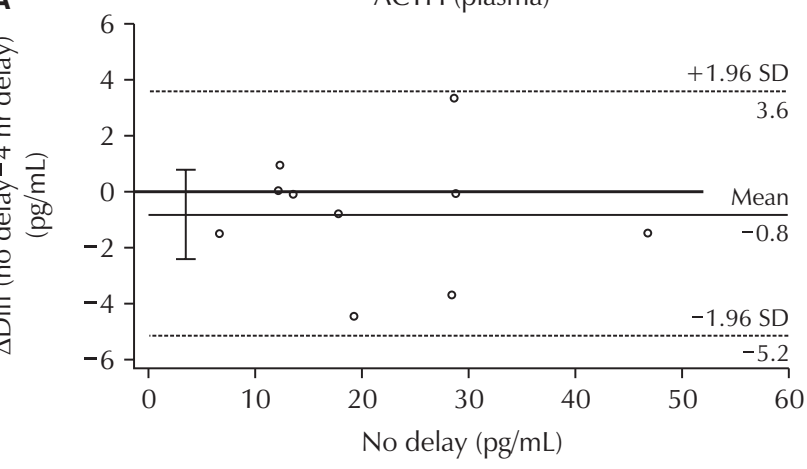

C
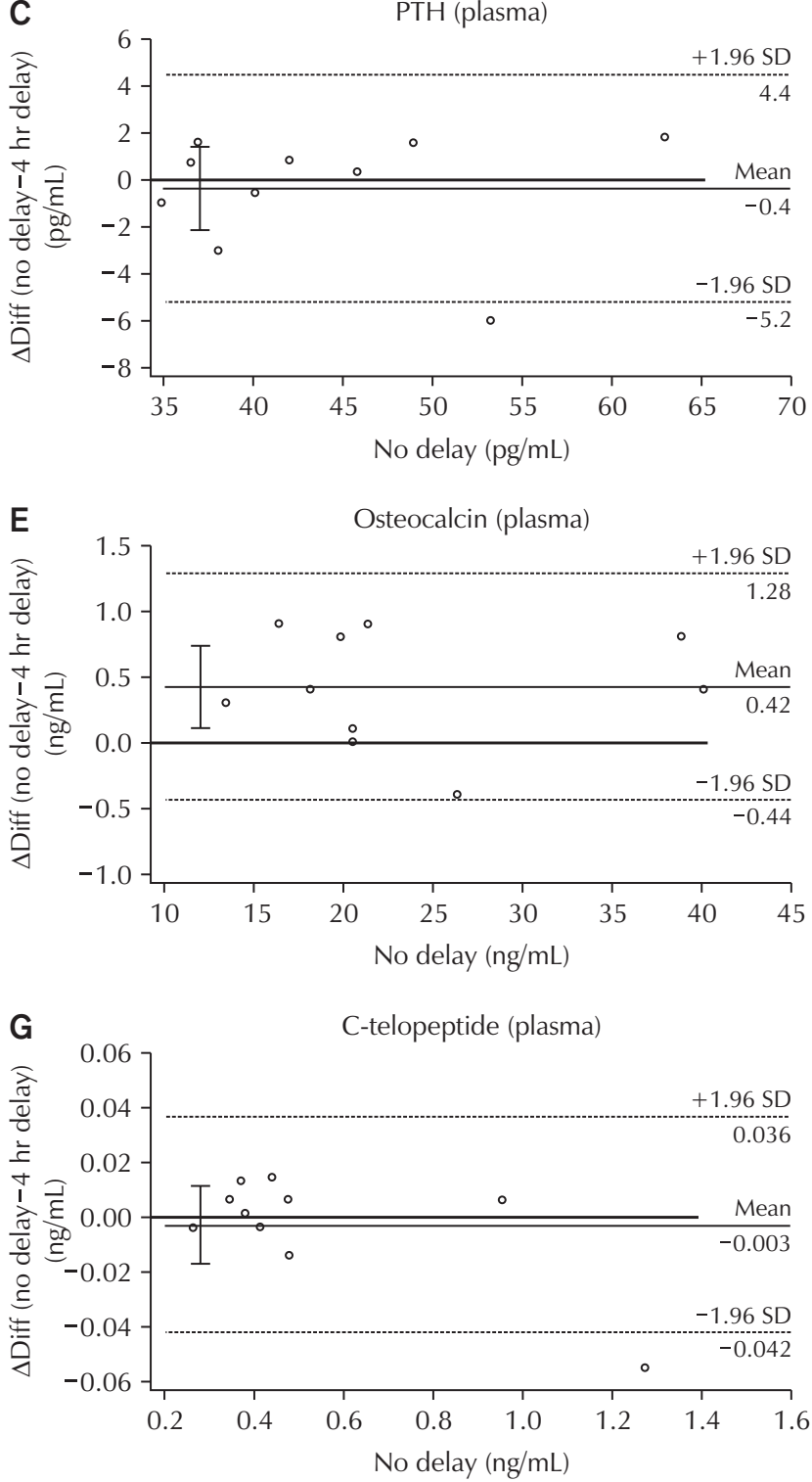

B

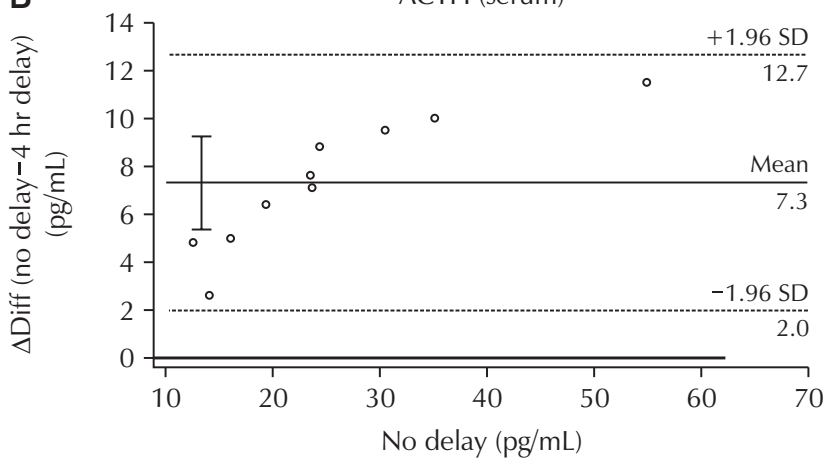

D
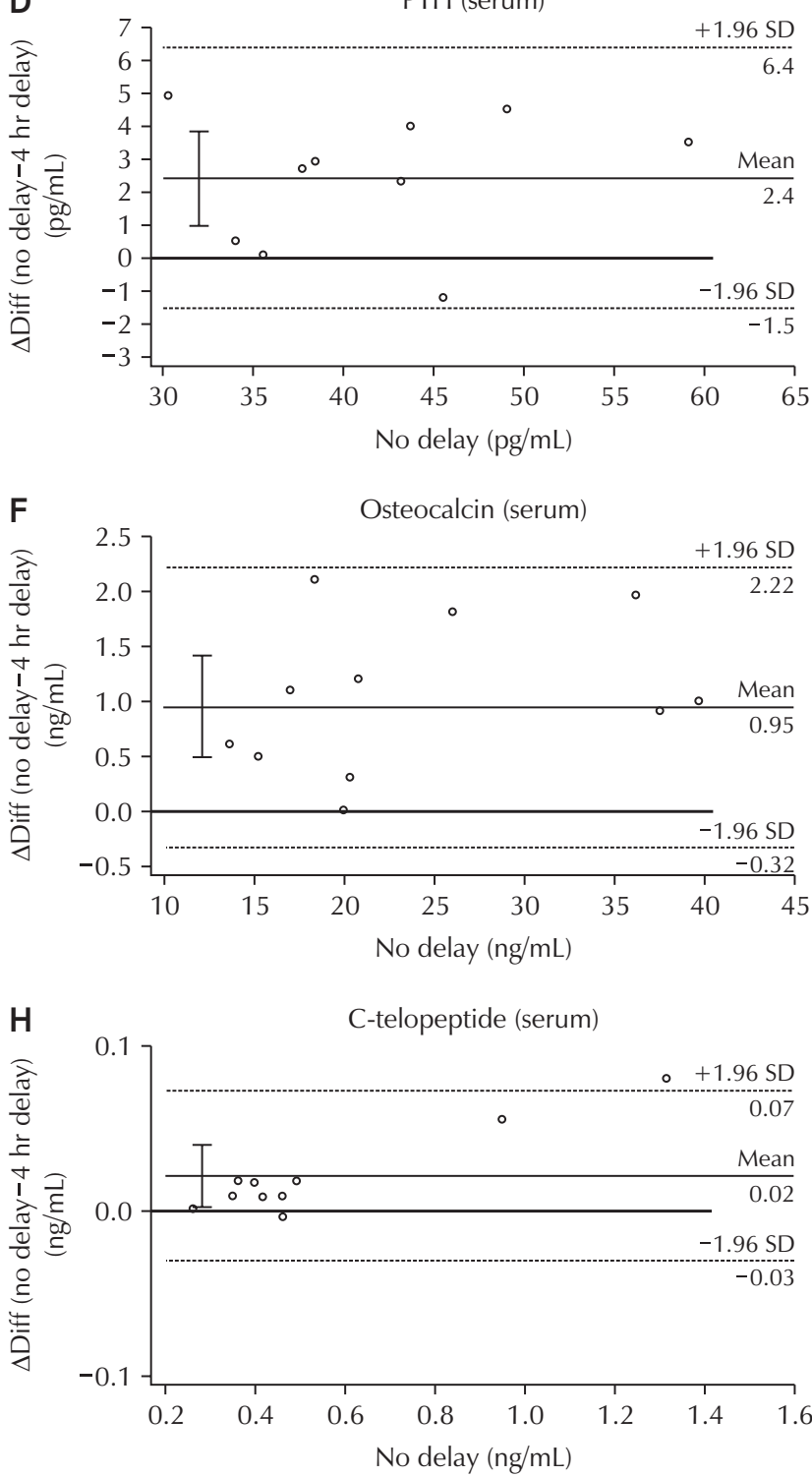

Fig. 2. (A-J) Difference plot illustrating the levels of biological analyte in plasma and serum samples separated within 1 hour (no delay) and after 4 hours (4-hour delay) post collection. Solid lines and dotted lines represent mean difference and $95 \%$ confidence interval, respectively. $\triangle$ Diff represents difference in analyte level. Abbreviations: ACTH, adrenocorticotropic hormone; PTH, parathyroid hormone; $\mathrm{SD}$, standard deviation (Continued on next page). 

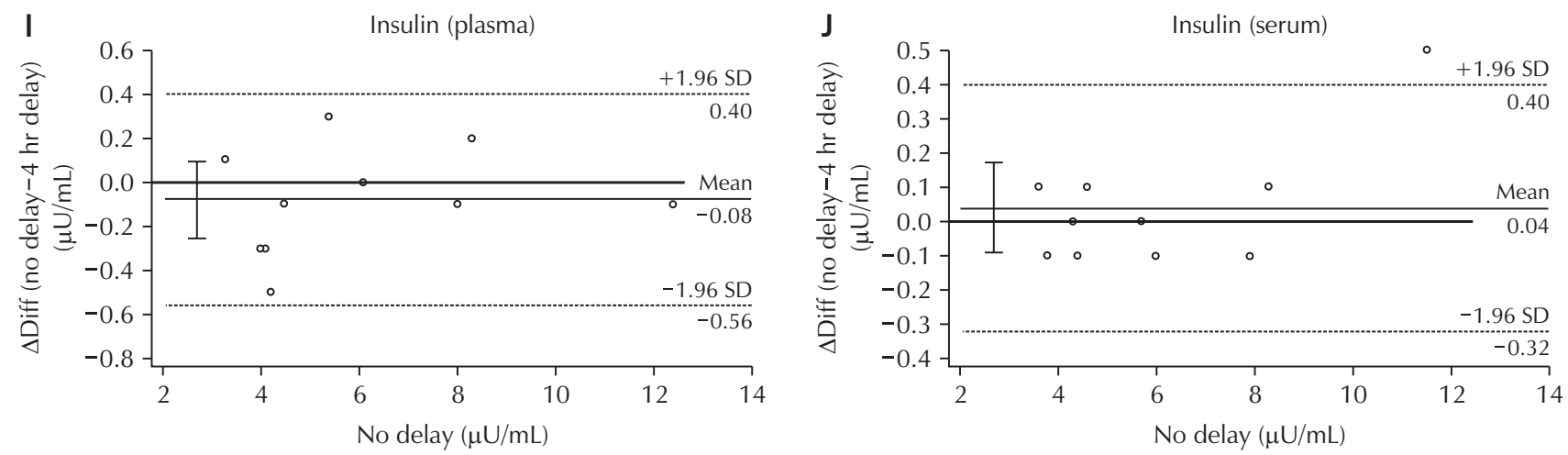

Fig. 2. Continued; caption shown on previous page.

A

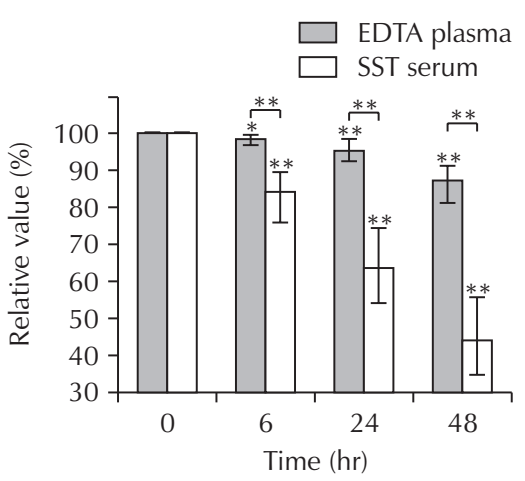

D

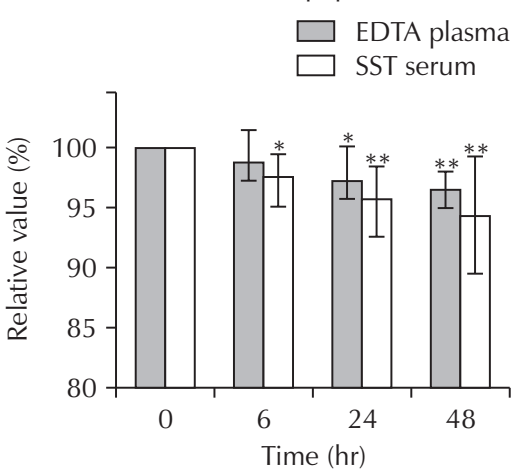

B

PTH

$\square$ EDTA plasma $\square$ SST serum

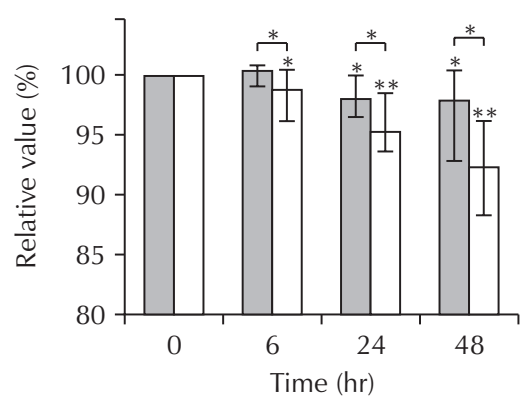

E
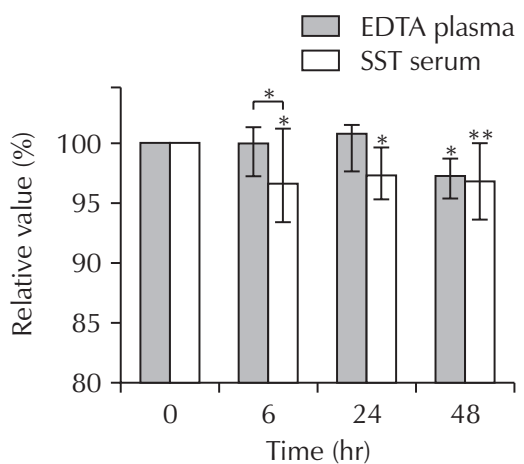

C

Osteocalcin

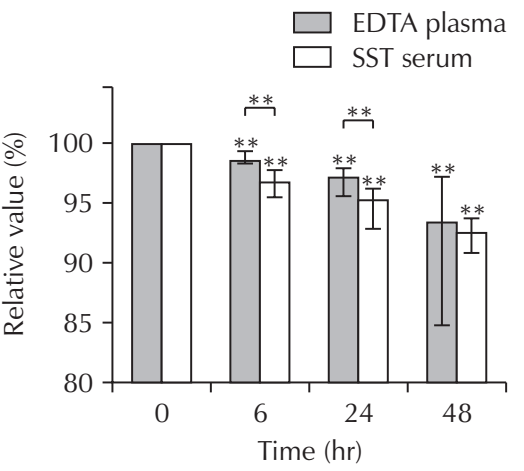

Fig. 3. The graph represents comparison between the levels of analyte measured before and after the storage at $4^{\circ} \mathrm{C}$ in plasma and serum samples separated within 1 hour after collection. Each group represents values obtained from 10 individuals ( $N=10)$. The samples were assayed at $0,6,24$, and 48 hours after storage at $4^{\circ} \mathrm{C}$. Bars and lines represent median value and interquartile range of the relative values (\% level at each time point compared to the level at 0 hour), respectively. The data were analyzed using Wilcoxon signed-rank test. Abbreviations: ACTH, adrenocorticotropic hormone; PTH, parathyroid hormone; EDTA, ethylenediaminetetraacetic acid; SST, serumseparating tube. ${ }^{\star} P<0.05 .{ }^{\star \star} P<0.01$.

등은 이미 잘 관리하여 시행하고 있다. 현재 ACTH 검사는 EDTA 혈장을 이용하고 있고 우송 시 동결 혈장을 보내도록 권장하고 있 으며, PTH, insulin, osteocalcin, C-telopeptide 검사항목들은 혈청이나 혈장으로 검사 가능하고 냉장 또는 냉동상태로 우송하
도록 안내하고 있다. 하지만 대부분 기관들에서 ACTH를 제외한 PTH, insulin, osteocalcin, C-telopeptide 검사에서는 통상적 으로 혈청을 사용하고 있다.

이번 연구에서는 실제 상황과 유사하도록 계획한 바, 오전 또 
A

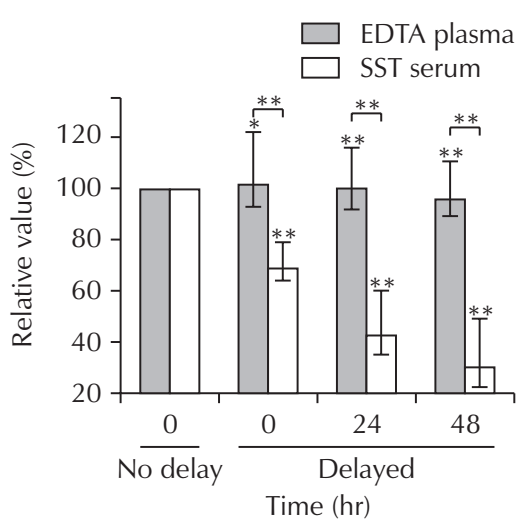

D

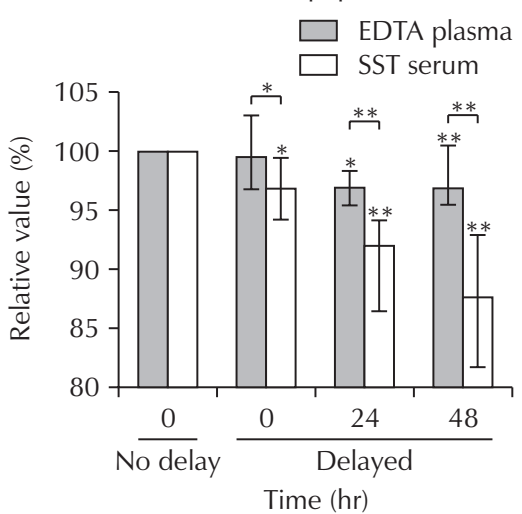

B

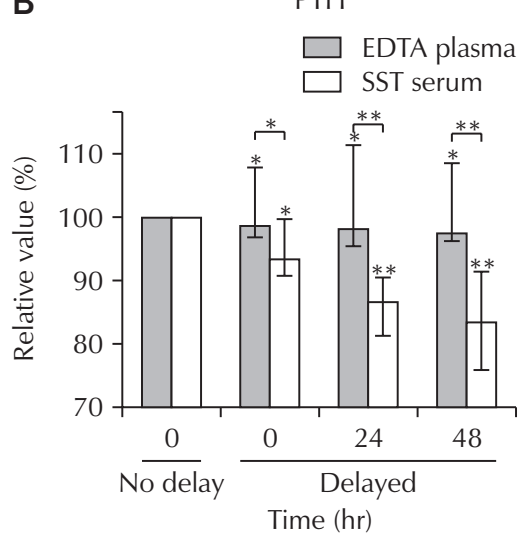

E

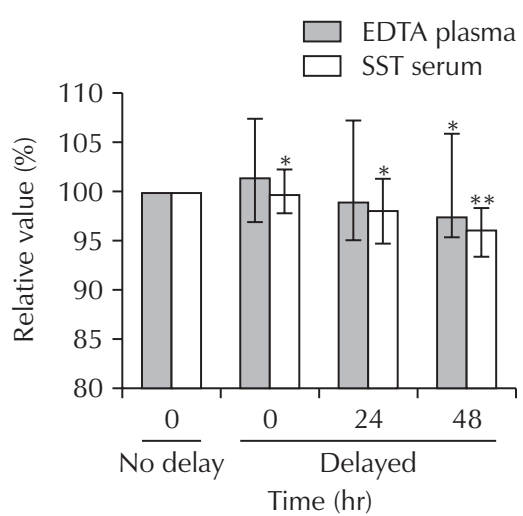

C

Osteocalcin

$\square$ EDTA plasma SST serum

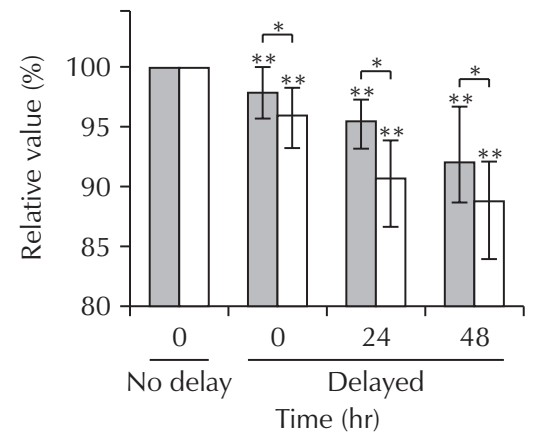

Time (hr)

Fig. 4. The graph represents comparison between the levels of analyte measured before and after the storage at $4^{\circ} \mathrm{C}$ in plasma and serum samples separated within 1 hour (no delay) and 4 hours (delayed) after collection. Each group represents values obtained from 10 individuals $(\mathrm{N}=10)$. The samples were assayed at different time points $(0,24$, and 48 hours) after separation in both the groups (no delay and delayed). Bars and lines represent median value and interquartile range of the relative values (\% level at each time point compared to the level at no delay 0 hour), respectively. The data were analyzed using Wilcoxon signed-rank test. Abbreviations: ACTH, adrenocorticotropic hormone; PTH, parathyroid hormone; EDTA, ethylenediaminetetraacetic acid; SST, serum-separating tube. ${ }^{\star} P<0.05$. ${ }^{*} P<0.01$.

는 오후에 한꺼번에 검체를 수거하여 원심분리하는 경우를 고려 하여 4시간 정도의 원심분리 지연을 가상하였고 원심분리 후 얻 어진 혈청이나 혈장 검체 보관조건도 냉장으로 국한하였다. 그럼 에도 불구하고 본 연구에서 분석한 ACTH, PTH, osteocalcin, C-telopeptide, insulin 검사에서 시간 지연에 따른 유의한 검사 결과의 변화를 확인할 수 있었으며, 특히 혈청에서 혈장보다 결과 의 변화 폭이 컸다.

검사 지연시간이 검체 결과 안정성에 영향을 미치는 원인에는 여러 가지가 있다. 혈장과 혈청이 혈액 내의 혈구세포와 분리되지 않은 상태로 상존하는 시간이 길어지면 세포 용혈현상에 의해 칼 륨, 마그네슘, 젖산탈수소효소(lactate dehydrogenase) 등의 수 치가 높아질 수 있고 적혈구, 백혈구, 혈소판 등의 세포에 의해 당 이 이용되므로 시간이 지날수록 혈당 수치가 감소하는 현상도 발
생한다. Oddoze 등[5]의 연구에 의하면 혈액 내에 존재하는 효 소에 의해 단백질이나 펩타이드의 분해현상이 발생하게 되는데, EDTA는 효소에 의한 단백질분해를 억제하는 성질을 가지고 있기 때문에 EDTA 튜브를 이용한 혈액 검체의 경우 검사결과에 있어서 더 높은 안정성을 보이게 되고 이 안정성은 온도에 따라서도 차이 를 보이게 되는데, 대부분의 호르몬검사에서 같은 EDTA 튜브 채 혈조건이라도 실온보다 냉장에서 더 오랜 시간 안정성을 보였다고 한다. 또 다른 연구에서는 EDTA 혈장 검체에서 PTH를 측정했을 때 혈청 검체와 달리 채취 후 3 일이 지난 시점에서도 안정적인 검 사결과를 기대할 수 있다고 밝힌 바가 있다[13].

제조사에서도 PTH와 C-telopeptide의 시약설명서에 EDTA 혈장이 혈청보다 더 선호된다고 명시하고 있고 osteocalcin 과 insulin의 경우 적혈구에 분해효소가 있어 빨리 검체를 응괴 
Table 4. Different parameters critical for measurement of biological analytes, including tubes, acceptable delays (suggested by the manufacturer), TAE, imprecision, and inaccuracy [16]

\begin{tabular}{|c|c|c|c|c|c|c|c|c|}
\hline \multirow{2}{*}{ Analytes } & \multirow{2}{*}{$\begin{array}{l}\text { ACTH } \\
\text { EDTA }\end{array}$} & \multicolumn{2}{|c|}{ PTH } & \multicolumn{2}{|c|}{ Osteocalcin } & \multicolumn{2}{|c|}{ C-telopeptide } & \multirow{2}{*}{$\begin{array}{c}\text { Insulin } \\
\text { EDTA }\end{array}$} \\
\hline & & EDTA & SST & EDTA & SST & EDTA & SST & \\
\hline \multicolumn{9}{|l|}{ Acceptable delays } \\
\hline Room temperature & $2 \mathrm{hr}$ & 2 day & $8 \mathrm{hr}$ & 2 day & $8 \mathrm{hr}$ & $24 \mathrm{hr}$ & $6 \mathrm{hr}$ & NA \\
\hline Refrigeration & $3 \mathrm{hr}$ & 3 day & 2 day & 3 day & 3 day & 8 day & $8 \mathrm{hr}$ & NA \\
\hline Frozen & $10 \mathrm{wk}$ & $6 \mathrm{mo}$ & $6 \mathrm{mo}$ & $3 \mathrm{mo}$ & $3 \mathrm{mo}$ & $3 \mathrm{mo}$ & $3 \mathrm{mo}$ & 7 day \\
\hline TAE (\%) & 10 & \multicolumn{2}{|c|}{30.2} & \multicolumn{2}{|c|}{13.3} & \multicolumn{2}{|c|}{15.45} & 32.9 \\
\hline Imprecision (\%) & NA & \multicolumn{2}{|c|}{13.0} & \multicolumn{2}{|c|}{3.18} & \multicolumn{2}{|c|}{5.43} & 10.6 \\
\hline Inaccuracy (\%) & NA & \multicolumn{2}{|c|}{8.8} & \multicolumn{2}{|c|}{7.89} & \multicolumn{2}{|c|}{8.12} & 15.5 \\
\hline
\end{tabular}

Abbreviations: TAE, total allowable error; ACTH, adrenocorticotropic hormone; PTH, parathyroid hormone; EDTA, ethylenediaminetetraacetic acid; SST, serum separating tube; NA, information not available.

나 적혈구로부터 분리하여야 한다고 명시하고 있다[7-10]. 특히 insulin의 경우 혈액 내에서의 안정성은 실온에서 15 분 정도로 알 려져 있고, 이후 적혈구 내의 insulin-degrading enzyme에 의 한 insulin 분해현상이 시작되기 때문에 즉각적인 원심분리를 필 요로 한다[14,15]. 이러한 분해효소들은 EDTA 첨가조건에서 활성 이 억제되므로 부득이하게 검체의 원심분리가 지연되는 현실 상황 에서 EDTA 혈장이 혈청보다 훨씬 검체 안정성 면에서 우수할 것 으로 기대할 수 있다. 그럼에도 불구하고 국내 검사실에서 이들 검 사를 위하여 혈청을 주로 이용하고 있고 EDTA 혈장을 우선적으로 권하는 안내는 찾아보기 힘들다. 이는 시급히 교정하여야 할 관행 으로 여겨진다.

각 시약의 제조사에서는 허용 가능한 최대 검사 지연시간을 명 시하고 있는데[16] (Table 4), 이 자료에서도 SST 혈청보다 EDTA 혈장에서 최대 검사 지연시간이 긴 것을 확인할 수 있다. $\mathrm{ACTH}$ 의 경우 EDTA 혈장만 사용하도록 하고 있으며 실온에서 안정성이 가 장 떨어지는 것으로 되어 있는데, 실제로 본 실험에서도 즉시 시행 한 검사에 비해 6시간 지연 후 시행한 검사에서 그 결과값이 유의 하게 감소하는 것을 확인할 수 있었다. 이는 ACTH 검사를 타 기관 에 위탁하여 수행할 경우 반드시 EDTA 혈장을 동결하여 우송하여 야 하며 이는 권장사항이 아니라 반드시 지켜져야 하는 필수사항 임을 의미한다. PTH와 osteocalcin은 제조사에서 명시한 것보다 더 짧은 검사시간 지연에도 결과값이 유의하게 감소하는 양상을
보였고 C-telopeptide도 비슷하게 제조사에서 제시한 지연 가능 시간범위 이전에 유의한 감소가 확인되었다. Insulin은 제조사에 서 따로 실온, 냉장온도에서의 지연시간을 명시하지 않았으나 채 혈 후 바로 검사하도록 권장하였고, 본 연구에서 EDTA 혈장은 48 시간 보관하여야 유의한 감소가 보였지만 SST 혈청은 6시간 보관 시점에서부터 감소가 유의하였다. 시약의 제조사의 허용 가능한 최대 검사 지연시간은 각 검사항목별로 총 허용 가능 오차범위에 근거하여 설정하기 때문에 연구에서의 유의미한 결과 변화 시점보 다 제조사의 최대 검사 지연시간이 더 넓게 제시되는 것으로 생각 된다[16] (Table 4). 이번 연구결과에서도 총 허용 가능 오차범위 를 벗어나는 결과값을 보인 검사항목은 ACTH 검사뿐이었다. 하지 만 총 허용 가능 오차범위란 분석 전, 분석 중, 분석 후 오차를 모두 포함하는 오차범위이므로 이러한 분석 전 오차가 총 허용 가능 오 차범위 안이라 하여 임상검사실에서 간과해도 된다는 의미는 아닐 것이다. 임상검사실에서는 보다 믿을 수 있는 검사결과 생산을 위 하여 검사에서 발생하는 오차를 가능한 줄일 수 있는 검체 우송방 법이나 검체 종류 개선의 노력을 계속하여야 하겠다.

\section{감사의 글}

이 논문은 대한임상검사정도관리협회 2019년 학술연구비 지원 에 의해 수행되었다(2019-05).

\section{REFERENCES}

1. Evans MJ, Livesey JH, Ellis MJ, Yandle TG. Effect of anticoagulants and storage temperatures on stability of plasma and serum hormones. Clin Biochem 2001;34:107-12.

2. Reisch N, Reincke M, Bidlingmaier M. Preanalytical stability of adrenocorticotropic hormone depends on time to 
centrifugation rather than temperature. Clin Chem 2007;53:358-9.

3. Guder WG, da Fonseca-Wollheim F, Heil W, Schmitt Y, Topfer G, Wisser H, et al. Quality of diagnostic samples: recommendations of the Working Group on Preanalytical Quality of the German Society for Clinical Chemistry and Laboratory Medicine. 2nd ed. Oxford: BD Diagnostics Preanalytical Systems, 2010.

4. Clinical and Laboratory Standards Institute. Procedures for the handling and processing of blood specimens for common laboratory tests: approved guideline: GP44-A4. 4th ed. Wayne (PA): Clinical and Laboratory Standards Institute, 2010.

5. Oddoze C, Lombard E, Portugal H. Stability study of 81 analytes in human whole blood, in serum and in plasma. Clin Biochem 2012;45:464-9.

6. Elecsys ACTH [package insert]. Indianapolis (IN): Roche Diagnostics Corp., 2016.

7. Elecsys PTH [package insert]. Indianapolis (IN): Roche Diagnostics Corp., 2016.

8. Elecsys N-MID osteocalcin [package insert]. Indianapolis (IN): Roche Diagnostics Corp., 2016.

9. Elecsys $\beta$-CrossLaps/serum [package insert]. Indianapolis (IN): Roche Diagnostics Corp., 2016.

10. Architect insulin [package insert]. Abbott Park (IL): Abbott Laboratories, 2012.

11. Lippi G, Guidi GC, Mattiuzzi C, Plebani M. Preanalytical variability: the dark side of the moon in laboratory testing. Clin Chem Lab Med 2006;44:358-65.

12. Jensen EA, Stahl M, Brandslund I, Grinsted P. Stability of heparin blood samples during transport based on defined pre-analytical quality goals. Clin Chem Lab Med 2008;46:225-34.

13. Glendenning P, Laffer LL, Weber HK, Musk AA, Vasikaran SD. Parathyroid hormone is more stable in EDTA plasma than in serum. Clin Chem 2002;48:766-7.

14. Shii K, Yokono K, Baba S, Roth RA. Purification and characterization of insulin-degrading enzyme from human erythrocytes. Diabetes 1986;35:675-83.

15. Vogeser M, Parhofer KG. Limited preanalytical requirements for insulin measurement. Clin Biochem 2005;38:572-5.

16. Ricos C, Alvarez V, Cava F, Garcia-Lario JV, Hernandez A, Jimenez CV, et al. Current databases on biological variation: pros, cons and progress. Scand J Clin Lab Invest 1999;59:491-500. 